\title{
ARTICLES
}

ROBERT A. KAHN*

\section{Who's the Fascist? Uses of the Nazi Past at the Geert Wilders Trial}

I. The Anti-Fascist Consensus ................................................. 280

II. Geert Wilders: A Typical Hate Speech Defendant?............... 283

III. The Symbolic Role of Jews and the Holocaust in Dutch

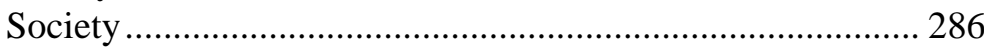

IV. Fighting in "The Good War" .............................................. 289

V. Perhaps Wilders Is a Fascist After All ................................. 293

VI. Like Jews in the 1930s .......................................................... 298

Conclusion: The Continuing Relevance of the Nazi Past ................. 300

But let us not forget that in the United States we have been blessed with two centuries of secure borders and political stability. Not so our European counterparts, who have experienced Nazism and other destructive social movements on their own soil. Their efforts to control their legacy of extremism should be respected, even if their methods are not ours. ${ }^{1}$

In the Netherlands Mein Kampf is outlawed. When it was outlawed, the politically correct leftist and liberal parties applauded it. My point was that for the same reason and (legal) arguments that Mein Kampf was outlawed in the Netherlands, the

\footnotetext{
* B.A. Columbia University, J.D. New York University School of Law, PhD (political science) Johns Hopkins University, Associate Professor, University of St. Thomas School of Law. An early version of this paper was presented at the University of St. Thomas Faculty Colloquium in February 2012. The author would like to thank Jacqueline Baronian, Mitchell Gordon, Robert Delahunty, Robert Vischer, Tom Berg, Virgil Wiebe, Joel Nichols, Jerry Organ, David Patton, and Charles Reid for their helpful comments.

1 Abraham Foxman, Introduction to Adolf Hitler, MeIN KAMPF xiii, xiv (Mariner Press 1999) [hereinafter Foxman, Introduction].
} 
Koran could and should be outlawed since both books are full of incitement of violence. ${ }^{2}$

\section{I}

\section{The ANTI-FAscist CONSENSUS}

European hate speech laws rest in part on the idea that Europe's past - in particular its Nazi past - creates a special situation, one that justifies restrictions on speech that would otherwise be incompatible with a liberal democracy. While this trend is most evident in laws that relate directly to the Nazi past (such as those banning denial or trivialization of the Holocaust) the issue is broader. ${ }^{3}$ To take one example, there is considerable concern about what will happen in Germany (and Europe) when the Bavarian Finance Ministry loses its copyright over the German language rights to Mein Kampf. ${ }^{4}$ With the copyright set to expire in 2015, the Finance Ministry has blocked an effort by German academics to release an annotated version of the book that would, through its comprehensive footnotes, "break the peculiar myth which surrounds Mein Kampf." 5 The Finance Ministry justified its decision as "preventing the distribution of Nazi ideology" and to showing "responsibility and respect for the victims of the Holocaust, for whom republication would always represent an affront ... to their suffering."6

This is not how Abraham Foxman, National Director of the AntiDefamation League, sees it. Foxman, despite having some sympathy for the European perspective, wrote an introduction to the Mariner Press edition of Mein Kampf appearing in the United States. Foxman called on his readers to: "Commit the evil to memory in order to

2 I Have No Regrets: An Interview with Geert Wilders, GEERT WILDERS WEBLOG (Jan. 22, 2010, 3:48 PM), http://www.geertwilders.nl/index.php?option=com_content\&task =view\&id=1642\&Itemid=1.

3 For an overview of the development of Holocaust denial laws in Europe, see Robert A. Kahn, Holocaust Denial and Hate Speech, in GENOCIDE DENIALS AND THE LAW 77108 (Thomas Hochmann \& Ludovic Hennebel eds., 2011).

4 David Gordon Smith, Should Germany Republish 'Mein Kampf'?, SPIEGEL ONLINE (July 17, 2007, 3:19 PM), http://www.spiegel.de/international/germany/putting-hitler-back -on-the-shelves-should-germany-republish-mein-kampf-a-494891.html.

5 Id. (quoting Horst Möller of the Institute for Contemporary History). Möller hopes the scholarly edition will end "the oft simple-minded speculation about what is actually in the book." Id.

$6 I d$. (quoting the statement of ministry spokeswoman Judith Steiner). More recently, the Finance Ministry has blocked an effort of a newspaper to reprint lengthy excerpts of Mein Kampf. See also David Rising, German State Questions Mein Kampf Publication Plan, DESERT NEwS (Jan. 17, 2012), http://www.deseretnews.com/article/700216210 /German-state-questions-Mein-Kampf-publication-plan.html. 
reject it; reject the evil, but do not let yourself forget it." ${ }^{7}$ In justifying the publication of Mein Kampf, Foxman referred to "two centuries of secure borders and political stability" in the United States. ${ }^{8}$ This stands in contrast to Europe where, in Faurisson v. France, the United Nations Human Rights Committee upheld the French Gayssot Act, which bans questioning the existence of the Holocaust, because of its potential to facilitate the spread of Nazism and anti-Semitism, both of which the court saw as continuing concerns in France. ${ }^{9}$

The use of the Nazi past to justify European hate speech laws is not a doctrinal necessity. Hate speech laws predated the Holocaust and there are other ways of rationalizing them-including as offshoots of an earlier European tradition of using law to protect one's honor. ${ }^{10} \mathrm{In}$ fact, one can adopt bright line rules - the clear and present danger test, the gravity of the evil test-that, in theory, are at least indifferent to the type of "danger" or "evil" on offer. ${ }^{11}$ For example, the Amsterdam trial court, in acquitting Geert Wilders of comparing the Quran to Mein Kampf and calling Islam a "fascist" religion, relied on the general principle that hate speech and group defamation charges cannot rest on insults directed at ideas or objects of religious veneration. ${ }^{12}$ So, clearly, there are other ways of defending (or

\footnotetext{
7 Foxman, Introduction, supra note 1, at xiv.

8 Id.

9 Faurisson v. France, Communication No. 550/1993 U.N. Doc. CCPR/C/58/D/550/1993, 甲ๆ 9.6-9.7 (Nov. 8, 1996).

10 See James Q. Whitman, Enforcing Civility and Respect: Three Societies, 109 YALE L.J. 1279 (2000) (describing Germany's nineteenth century culture of dueling as a source of German insult laws). On the other hand, the decision to expand earlier traditions of speech restriction to cover speech based on anti-Semitism and racism may well owe something to the Nazi experience. See Robert A. Kahn, Cross-Burning, Holocaust Denial, \& the Development of Hate Speech Law in the United States \& Germany, 83 U. DET. MERCY L. REV. 163, 184-86 (2006).

11 For a brief overview of these doctrines, see HARRY KALVEN JR., A WORTHY TRADITION: FREEDOM OF SPEECH IN AMERICA 179-89, 195-99 (Jamie Kalven ed., 1988). For an example of this categorical approach to speech in action consider Flemming Rose, culture page editor of the Jyllands Posten, who played a major role in the publication of the Danish cartoons. Speaking in Jerusalem after the controversy, Flemming-who has become something of a free speech advocate-asked Israel to end its ban of Mein Kampf. See Robert A. Kahn, Flemming Rose, the Danish Cartoon Controversy, and the New European Freedom of Speech, 40 CAL. W. INT'L L.J. 253, 258-65 (2010).

12 Amsterdam District Court, 23 June, 2011, Public Prosecution \# 13/425046-09, at § 4.3.2. [hereinafter Wilders Verdict] ("Since the suspect addresses the religion and not the people (Muslims) with these utterances, it cannot be proven beyond any reasonable doubt that he incites to hatred against and/or discrimination of Muslims with these utterances, as was charged against him.”) (emphasis in original). For a brief overview of how Wilders's acquittal was seen in Dutch society, see Robert A. Kahn, The Acquittal of Geert Wilders and Dutch Political Culture, University of St. Thomas Legal Studies Research Paper No.
} 
critiquing) European hate speech laws besides focusing their responsiveness to the Nazi past. ${ }^{13}$

Yet references to the Nazi past loomed large at the Geert Wilders trial. While this owes something to Wilders's explicit comparison of the Quran and Mein Kampf, it also reflects societies - the Netherlands and, more generally, Europe - that still view themselves through the prism of the Second World War. Thus Wilders was eager to portray himself as a participant in the "good war" against Nazism. ${ }^{14}$ On the other side, opponents called Wilders a fascist ${ }^{15}$ and argued that Dutch Muslims were in the same situation as Dutch Jews before the Holocaust. ${ }^{16}$ These references, paradoxically, occurred in a country where anti-Semitism remains prevalent in both the native Dutch and immigrant communities. ${ }^{17}$

Before proceeding, let me offer a caveat. I am not saying references to the Nazi past drove the outcome of the trial-Wilders was acquitted and the Mein Kampf / Quran comparison was not the only charge Wilders faced. ${ }^{18}$ But the competing claims about Nazism and victimhood provide a way to frame the trial, one the participants seemed to find compelling. Was Geert Wilders a Nazi in training or were Muslim followers of the Quran the true Nazis? And were Dutch Muslims like Jews before the Holocaust, or was Israel continuing "the good war” the Western Allies waged against Hitler?

The rest of this essay explores these questions in greater depth. Part II looks at the extent to which Wilders fits the model of the typical

11-31, http://papers.ssrn.com/sol3/papers.cfm?abstract_id=1956192 (posted Nov. 8, 2011).

13 See Robert Post, Hate Speech, in EXTREME SPEECH AND DEMOCRACY 123-38 (Ivan Hare \& James Weinstein eds., 2009) (taking a critical view of European hate speech laws); Peter R. Teachout, Making "Holocaust Denial" a Crime: Reflections on European AntiNegationist Laws from the Perspective of U.S. Constitutional Experience, 30 VT. L. REV. 655, 688 (2006) (viewing laws against Holocaust denial from the perspective of the First Amendment).

14 See infra notes 51-70 and accompanying text.

15 See infra notes 71-104 and accompanying text.

16 See infra notes 105-15 and accompanying text.

17 See infra notes $32-50$ and accompanying text.

18 Wilders was also prosecuted for saying in an interview that if elected he would "[close the] borders, [and allow] no more Islamic people coming to the Netherlands." Wilders Verdict, supra note 12 (describing utterance 11). Other comments targeted immigrants and Moroccans. For example, utterance 7 describes Moroccan boys as "violent," while utterance 8 talks about the Netherlands facing a "tsunami" of foreign cultures. Id. For a list in English of the charges against Wilders, see Summons of the Accused, District Court Office of the Public Prosecutor, Jan. 20, 2010, available at http://www.geertwilders.nl/images/PDF/dagvaarding_ENG.pdf [hereinafter Wilders Summons]. 
hate speech defendant. While opponents tried to pin the "fascist" label on him, Wilders's opposition to anti-Semitism (among Europeans as well as Muslims) complicated this effort. To put Wilders's opposition to anti-Semitism in context, Part III looks at the complex role Jews play in Dutch society-a role that far outstrips the numerical importance of the small Dutch Jewish community.

Part IV looks at how Wilders, when discussing Islam, often makes references to the Second World War. In particular, he often represents himself as fighting the same struggle as the victorious Western Allied armies, especially the Americans. At times he also compares Muslims (and their leftist allies) to the defeated Nazi German forces.

The next two sections turn the tables and look at how his opponents describe Wilders. Part V looks at efforts by opponents to label Wilders a fascist because of his blunt rhetorical style and his attacks on the left and Islam. Part VI turns to an indirect argument: even if Wilders is not a fascist, his victims - the Muslims-are like Jews before the Holocaust.

Finally, the Conclusion looks at the implication of the Wilders trial for the anti-fascist consensus that helps uphold European hate speech laws. With the passage of time, it is tempting to argue that the Holocaust has become history and that Europe's hate speech laws are outdated. $^{19}$ The Wilders trial, however, points in a different direction-nearly seventy years after the end of World War II, Europeans still find the Nazi past (and hate speech laws) relevant.

\section{II}

\section{GEERT WILDERS: A TYPICAL HATE SPEECH DEFENDANT?}

Geert Wilders, leader of the anti-immigrant Party for Political Freedom (Partij voor de Vrijheid-PVV), faced hate speech charges for comments targeting Muslims and Islam. ${ }^{20}$ While many of these comments directly invoked the Nazi era-as, for example, when Wilders said "walk in the street and see where this ends" and "a conflict is going on and we have to defend ourselves" 21 - other counts were different. For example, in a 2007 article that ran in De Volkskrant, a center-left Amsterdam-based paper, Wilders called for a ban of the Quran, which he called a "fascist" book and an "Islamic

\footnotetext{
19 Peter Teachout makes this argument. See Teachout supra note 13, at 688-92.

20 For an overview of the Wilders trial and how the acquittal was received in Dutch society, see Kahn, supra note 12, at 2-4.

21 Wilders Verdict, supra note 12, at $\S$ 4.3.2. The court found that these comments reached "the border of what is accepted pursuant to criminal law." Id.
} 
Mein Kampf.,"22 In his film Fitna, Wilders shows video clips in which Muslims are saying "God Bless Hitler" and "[b]e prepared for the real Holocaust." 23

Wilders's comments, and the decision to prosecute them, raise an interesting question-who was the real fascist? Was it Wilders who, as the leader of a right-wing anti-immigrant party was often seen as following in the footsteps of Jean-Marie Le Pen and Jorg Haider, to say nothing of the "original Nazis?"24 This was certainly how Henk Bovekerk saw it. Bovekerk was a college student who received a "10" (the highest score possible) for an undergraduate thesis concluding that Wilders was a "fascist" and the PVV a "fascist" party. ${ }^{25}$ Nor was he alone. Job Cohen, former Amsterdam mayor (2001-10) and current leader of the Dutch Labor Party (Partij van de Arbeid - PvdA) has compared the situation of Dutch Muslims to Jews in the 1930s, a comparison that carries weight given that two of Cohen's grandparents died in the Holocaust. ${ }^{26}$

At the same time, however, Wilders uses anti-fascist rhetoric against his Islamic foes. In explaining why the Quran, like Mein Kampf, should be banned, Wilders says that the former "should never, absolutely never, be used as a source of inspiration or an excuse for

22 Geert Wilders, Enough is Enough: Ban the Koran, GEERT WILDERS WEBLOG (Aug. 10, 2007, 10:04 PM), http://www.geertwilders.nl/index.php?option=com_content\&task =view\&id=1117.

23 Wilders Summons, supra note 18 (describing Fitna).

24 In France, Jean-Marie Le Pen's anti-immigrant National Front party rose to prominence in the 1980s. Since then Le Pen has repeatedly "let the mask drop" by referring to the Holocaust as "a point of detail in . . history" and noting that the name of a center-right Jewish minister rhymed with crematoria. See Jonathan Marcus, THE NAtional Front \& French Politics: The Resistible Rise of JeAN-MARie Le PEN 125-29 (1995). Likewise, in Austria Joerg Haider, who rose to prominence in the 1980s as the head of the Freedom Party, commented that the Third Reich had "an orderly employment policy" and that the Nazi SS should be honored. See Profile: Controversy and Joerg Haider, BBC NEWS (Feb. 29, 2000, 3:56 GMT), http://news.bbc.co.uk/2/hi/europe /464260.stm. For more on Haider, see THE HAIDER PhenOMENON In Austria (Ruth Wodak \& Anton Pelinka eds., 2002).

25 Henk Bovekerk, Prototypical Fascism in Contemporary Dutch Politics (Fall 2011) (unpublished B.A. Thesis, Tilburg University, available at http://universonline.nl/wp -content/uploads/2012/01/BA-Thesis-Henk-Bovekerk.pdf). The high marks led to an outpouring of criticism. See Student Krijgt 10 voor Scriptie Over "Fascistische PVV, ” DE VolKSKRANT, Jan. 6, 2012; Jan Dirk Snel, Tien voor Scriptie Over PVV Schaadt Universiteit, DE VOLKSKRANT, Jan. 11, 2012.

26 Cohen: Moslims Worden Buitengesloten, Zoals Joden in de Jaren Dertig, VRIJ NEDERLAND, Dec. 15, 2010. Cohen, whose paternal grandparents perished at BergenBelsen, spoke about how the current situation was similar to the exclusion of Jews his mother witnessed during the Nazi occupation of the country. Id.; Russell Shorto, The Integrationist, N.Y. TIMES SUNDAY MAG., May 28, 2010, at MM24. 

Geert Wilders Trial

violence"27 - a message on one level quite similar to the Bavarian Finance Ministries' justification of its ban on Mein Kampf. In his email interview with Human Rights Service, Wilders made the same argument: "both books are full of incitement of violence., ${ }^{28}$ While one can argue that the very act of comparing the Quran and Mein Kampf itself had Nazi overtones, ${ }^{29}$ Wilders's framing of nonviolence makes it harder to place him with right-wing extremists who see violence as acceptable and Mein Kampf as a source of inspiration. ${ }^{30}$

But Wilders goes further. In a September 2011 speech in Berlin he said that Germany needed a right-wing party "not tainted by ties to neo-Nazis and by anti-Semitism," adding that the cause of the war was not Germany, but "national-socialism."31 In January 2012 he supported the unsuccessful call on the Dutch government to issue a formal apology for its "passivity" during the Holocaust. ${ }^{32}$ These statements would appear to separate Wilders from the kind of person the hate speech laws are supposed to protect against.

27 Wilders, supra note 22.

28 Wilders, supra note 2.

29 See Liz Fekete, The Muslim Conspiracy Theory and the Oslo Massacre, 53 RACE \& ClAss 30, 36 (2011) (comparing Fitna to Joseph Goebbels' film The Eternal Jew in the way both send "subliminal messages" about the other "through the juxtaposition of images").

30 Compare Wilders to Anders Breivik, who killed seventy-seven people in Norway to defend against a Muslim conspiracy. Breivik cited Geert Wilders 30 times in a manifesto justifying the killings. $I d$. at 32 . Wilders took great pains to disassociate himself from Breivik after the event, stating that "we must never use violence" and that "Islam can be successfully fought with democratic means." Geert Wilders, Speech in Berlin (Sept. 3, 2011) (available at http://www.geertwilders.nl/index.php/component/content/article/87 -news/1764-speech-geert-wilders-in-berlin-3-september-2011-english-version. This, however, did not upset Breivik who saw Wilders's comments as "expected" and motivated primarily by Wilders's need, as a politician, to protect his reputation. See Fekete, supra note 29 , at 32.

31 Wilders, supra note 30.

32 The issue came to a head in January 2012. One of the charges involved the failure of Queen Wilhelmina or the Dutch government in exile to speak out about the Holocaust. According to Els Borst, former deputy prime minister and member of the left-liberal D66 party, the Queen "hardly concerned herself with the persecution of the Jews" and the prime minister did not believe the Jews were "real Dutchmen." Will Holland Finally Apologize for Passivity in the Holocaust?, IsRAel NATIONAL NEWS (Jan. 5, 2012), http://www.israelnationalnews.com/News/News.aspx/151452\#.UCuF09Ce7ZQ.

According to the Dutch News, Wilders was "scathing" in his remarks about the passivity of Queen Wilhelmina's government. Dutch State: Sorry, We're Not Apologizing, DuTCHNEWS.NL (Jan. 11, 2012), http://www.dutchnews.nl/features/2012/01/dutch_state _sorry_were_not_apo.php. 


\section{III}

\section{THE SyMbolic Role OF JeWS AND THE Holocaust IN DUTCH SOCIETY}

This brings us to the interesting role Jews and Israel play in Wilders's discourse. One of the strange effects of the Holocaust has been to make the symbolic role of the Jews in postwar European societies increase, even as the absolute numbers decline. Protecting against anti-Semitism is a major reason for hate speech laws. For example, in 1979 the German Federal Supreme Court, in ruling that a Holocaust denial case could be brought under Germany's laws against insult, held that the defendant's estimate that only 2,000,000 Jews were killed in the Holocaust was a "direct attack" on the "selfconception" of Jews living in Germany. ${ }^{33}$ The well being of German Jews, in turn, helped reassure Germans they were following their moral obligations arising out of the Holocaust. ${ }^{34}$

A similar situation exists in the Netherlands where the large number of Jews who perished (74\% of the prewar Jewish population, the highest percentage in Western Europe), ${ }^{35}$ the use of the Dutch civil service to prepare lists of Jews to deport ${ }^{36}$ and the willingness of many Dutch to "accommodate" the Nazi occupier led, by the 1960s and $70 \mathrm{~s}$, to considerable feelings of guilt. ${ }^{37}$ At the same time, however, a large minority of Dutch (31\%) think Jews talk too much about the Holocaust, and a majority (53\%) would find a Jewish prime minister unacceptable (even though Job Cohen was the Labor Party candidate for prime minister in 2003). ${ }^{38}$ To quote Manfred

33 See Robert A. Kahn, Holocaust Denial and the LaW: A Comparative STUDY 18 (2004) (describing the ruling).

34 Id.

35 Manfred Gerstenfeld, Anti-Semitism and Hypocrisy in Dutch Society, JERUSALEM CENTER FOR PUBLIC AFFAIRS (July 2004), http://www.jcpa.org/phas/phas-22.htm.

36 Bob Moore, Victims and Survivors: THE NAZI PERSECUtion of the JeWs in THE NETHERLANDS, 1940-1945, at 194-99 (1997) (describing role of Dutch civil service in the Holocaust).

37 For a good overview of the Holocaust in the Netherlands, see $i d$. For a discussion of the playing out of the Holocaust in postwar Dutch society, see F.C. Brasz, After the Second World War: From "Jewish Church" to Cultural Minority, in THE HISTORY OF THE JEWS IN THE NETHERLANDS 336, 385-91 (J.C.H. Blom, R.G. Fuks-Mansfeld \& I. Schöffer eds., Arnold J. Pomerans \& Erica Pomerans trans., Litman Library of Jewish Civilization 2002) (describing the extent of guilt feelings). According to Brasz, sentiments about the registration led many to sabotage the 1971 Dutch census after which further censuses were discontinued. $I d$. at 387.

38 Manfred Gerstenfeld, Symbolic and Other Roles of Jews in Dutch Society, JeRUSAlem CENTER FOR PUBLIC AFFAIRS (Dec. 23, 2008), available at http://jcpa.org /article/symbolic-and-other-roles-of-jews-in-dutch-society/. 
Gerstenfeld, a Holocaust survivor who grew up in the Netherlands, went into hiding, and is now one of the driving forces behind the request for an official apology: "Dead Jews and their past indeed often play a more important role in The Netherlands than the living.”39

There have also been incidents of anti-Semitism. The newspaper Trouw last year left an anonymous comment on its website blaming Jews for the rise of Hitler. ${ }^{40}$ Another set of anti-Semitic incidents involve young immigrants, especially Moroccans - some of which have led to violence against "visible" Jews (i.e., those wearing religious clothing).$^{41}$ Finally there are a number of Holocaust related anti-Semitic slogans used by soccer fans. ${ }^{42}$ These are directed at fans of the Ajax Amsterdam soccer team, who refer to themselves as "the Jews." 43 These slogans have been picked up and embellished by Moroccan and Turkish rappers, who also use "the Jew" as a symbol of "hegemonic Dutch society.",4

There have been a variety of responses to the upsurge in antiSemitism. On the one hand, the government has used "decoy Jews" to catch potential wrongdoers. ${ }^{45}$ Others have been less supportive. For

39 Id. A similar logic led the Anne Frank House Museum to refuse a screening of an award winning film about Anne Frank's time in the concentration camps. The Museum director based her objection on the following argument (according to the director of the film): "Anne Frank is a symbol. Symbols should not be shown dying in a concentration camp.” Id.

40 See Tundra Tabloids, Dutch Christian Daily Allows Anti-Semitic Tropes in its Comments, VlaD TEPES (Oct. 11, 2011), http://vladtepesblog.com/?p=38875.

41 See Gerstenfeld, supra note 35, at 5-6.

42 One of the main chants goes "Hamas, Hamas, Jews to the Gas.” Wim Dohrenbusch, Anti-Semitic Incidents Spark Public Debate in the Netherlands, DeUTSCHE WelLe (Apr. 23, 2011), available at http://www.dw.de/dw/article/0,,15023408,00.html.

43 Consequently, many of the fans and players who use the chant deny its anti-Semitic content. For example, Lex Immers, a midfielder for the ADO Den Haag team who was banned for five games for using the chant, explained that "[he] didn't mean it the way they think," explaining "the Jews" is a nickname for Ajax Amsterdam. Id. The problem of offensive slogans is not limited to the Netherlands or the postwar context. See Sarah Lyall, Taking on Soccer Violence, One Derogatory Chant at a Time, N.Y. TIMES, Jan. 27, 2012, at D1 (describing Scottish football slogans that refer back to seventeenth century events).

44 See Remco Ensel, The Sound of Anti-Semitism in Dutch Society 8 (Sept. 2010) (unpublished draft presented at the Conference on Ethnic Relations, Racism and AntiSemitism at Queen's University Belfast) (available at http://www.dutchantisemitism .nl/Content/Dutchantisemitism/The\%20Sound\%20of\%20Antisemitism.pdf). On the other hand, some rappers have rejected anti-Semitic appeals. According to Ali B., a well-known rapper: "The Prophet Muhammad, by the way, has reproved of what these tough youngsters do. When you believe in Allah you would never shout 'cancerous Jews.'” $I d$.

45 Aliyah Shahid, An Unorthodox Approach: Dutch Use Decoy Jews to Stop Crime and Anti-Semitic Attacks in Amsterdam, DAILY NEWS (Jun. 23, 2010), http://articles.nydaily 
instance, Fritz Bolkestein, notable for his 1991 call for a public critique of multiculturalism, has now called on "sensible Jews" to consider emigrating to Israel or the United States because "they have no future in the Netherlands." ${ }^{46}$

Perhaps unsurprisingly, Wilders takes issue with Bolkestein. It is not the Jews, but violent Muslims, who should leave the Netherlands. ${ }^{47}$ Protection of Jews is a theme of his speeches, especially those given in the United States. In Nashville, Tennessee, Wilders spoke about how "Jews are no longer safe on our streets. In Amsterdam, the city of Anne Frank." 48 At the Four Seasons Hotel in New York, just after he learned he would stand trial for hate speech, Wilders complained of a Dutch "elite" that had "lost its decency" by financing or participating in demonstrations where "settlers" shout "Death to the Jews."49 "Seventy years after Auschwitz," he continued, "they know of no shame."50

Paul Sars, Dean of the Humanities Faculty at the University of Nijmegen, was also outraged at Bolkestein's remarks but questioned Wilders's motives: "He is against Islam . . . By taking this stance, he can say that [he] is pro-Israel and against ... . [e]verything that's alien to the Netherlands." 51 But Wilders's stance gets him something else as well. By opposing Bolkestein, who was once his mentor, Wilders reinforces his image as a defender of Dutch Jews—not just against Muslims, but also against Dutch anti-Semitism and passivity. This reinforces his worldview in which Dutch elites are unable to solve the nation's problems, be they Nazi occupation or Islamic immigration. This, as well, makes Wilders an atypical hate speech defendant.

\footnotetext{
news.com/2010-06-23/news/27068034_1_anti-semitic-attacks-jews-decoy. The program, which has been successful, was the suggestion of a Moroccan born member of parliament. Id.

46 Dohrenbusch, supra note 42.

$47 \mathrm{Id}$.

48 Geert Wilders, Speech in Nashville, Tennessee, (May 12, 2011) (available at http://www.geertwilders.nl/index.php/in-english-mainmenu-98/in-the-press-mainmenu -101/77-in-the-press/1750-a-warning-to-america-speech-geert-wilders-cornerstone-church -nashville-12-may-2011).

49 Geert Wilders, Speech at the Four Seasons Hotel, New York, (Feb. 23, 2009) (available at http://www.geertwilders.nl/index.php/component/content/article/87-news /1535-speech-geert-wilders-new-york-four-seasons-monday-feb-23-2009).

$50 \mathrm{Id}$.

51 Dohrenbusch, supra note 42.
} 


\section{IV \\ FIGHTING IN “THE GOOD WAR”}

There is a second way Wilders uses the past to build sympathy for his position. He often makes references to the Western Allies during Second World War, especially to the Americans. In this way, he shows himself as fighting alongside the Americans in "the good war" against Hitler and the Nazis. ${ }^{52}$

Some of the references relate to Israel, where Wilders lived for two years as a teenager. ${ }^{53}$ On a grand historical level, these comparisons are not hard to follow. To the extent one views Islam as the next totalitarian movement, and Israel as a "frontline" state, it is not hard to see the Israelis fighting to protect "the West" from Islamic encroachment. ${ }^{54}$ But Wilders's references to the Second World War are much more specific. For example, at an October 2009 speech at Columbia University, he compared young men and women defending Israel to "those brave American soldiers who landed in Sicily in 1943 and stormed the Normandy beaches in 1944." 55

Nor is this an isolated instance. Speaking again in New York City, this time on the ninth anniversary of 9/11, Wilders invoked the words of Ronald Reagan forty years after the D-Day landings: "We will always remember. We will always be proud. We will always be

52 The idea of referring to the Second World War as "the good war" comes in part from Studs Terkel's oral history of Americans in the war. STUDS TERKEL, "THE GOOD WAR": AN ORAL HISTORY OF WORLD WAR TWO (1984). TOM BROKAW, THE GREATEST GENERATION (1998) similarly portrays American involvement in the war in a positive light. Not everyone shares the views of Brokaw and Terkel. See Ashley Smith, World War II: The Good War?, 10 INT'L SOCIALIST REV. (2000), available at http://www .isreview.org/issues/10/good_war.shtml (arguing that if one looks seriously the "good war" myth, the United States has nothing to boast about).

53 For a brief overview of Wilders's childhood and teenage years, see Christopher Dickey, Geert Wilders Says There's No Such Thing as Moderate Islam, THE DAILY BEAST (Jan. 16, 2012), http://www.thedailybeast.com/newsweek/2012/01/15/geert-wilders-says -there-s-no-such-thing-as-moderate-islam.html.

54 For example, Tom A. Trento, founder of "The United West" has issued a call to "[s]tand with Israel" to "[p]rotect [f]reedom and [d]emocracy ... [i]n America, [i]n Israel, and throughout Western Civilization.” Tom Trento, Stand With Israel - Protect Freedom and Democracy (May 23, 2011), http://theunitedwest.org/activism-alert/proclamation/. The group was formed by national security professionals "to change the ground game on how America protects liberty and freedom ... from Shariah Islam.” Id.

55 Geert Wilders, Speech at Columbia University, New York, (Oct. 21, 2009), (available at http://www.geertwilders.nl/index.php/component/content/article/87-news /1604-speech-geert-wilders-mp—columbia-university-new-york-october-21-2009) (quoting Ronald Reagan). 
prepared, so that we may always be free."56 Speaking to a Nashville, Tennessee audience in May 2011, Wilders noted that "[m]any American soldiers, including many young Tennesseans, played a decisive role in the liberation of the Netherlands from [N]azi tyranny," and, speaking on behalf of the Dutch people, expressed thanks.

Now one might be tempted to dismiss these references as an attempt to please American audiences or, in the Nashville speech, as simple politeness. This is harder to do with Wilders's remarks at the Four Seasons Hotel in 2009, in which he made an extended comparison between American forces during the Battle of the Bulge and the fight against Islam. It is worth quoting Wilders at length:

Late December 1944 the American army was suddenly faced with a last-ditch effort by the Germans. In the Ardennes, in the Battle of the Bulge, Hitler and his national-socialists fought for their last chance. And they were very successful. Americans faced defeat, and death.

In the darkest of winter, in the freezing cold, in a lonely forest with snow and ice as even fiercer enemies than the Nazi war machine itself, the American army was told to surrender. That might be their only chance to survive. But General McAuliffe thought otherwise. He gave the Germans a short message. This message contained just four letters. Four letters only, but never in the history of freedom was a desire for liberty and perseverance in the face of evil expressed more eloquently than in that message. It spelled N-U-TS. "Nuts."

My friends, the national-socialists got the message. Because it left no room for interpretation!

I suggest we walk in the tradition of giants like General McAuliffe and the American soldiers who fought and died for the freedom of my country and for a secular and democratic Europe, and we tell the enemies of freedom just that. NUTS! Because that's all there is to it. No explanations. No beating around the bush. No caveats.

Our enemies should know: we will never apologize for being free men, we will never bow for the combined forces of Mecca and the left. And we will never surrender.

\footnotetext{
56 Geert Wilders, New York City Speech (Sept. 11, 2010) (available at http://www.geertwilders.nl/index.php/component/content/article/80-geertwildersnl/1712 -nyc-speech-geert-wilders).

57 Geert Wilders, A Warning to America-Speech at Cornerstone Church, Nashville, Tennessee (May 12, 2011) (available at http://www.geertwilders.nl/index.php/in-english -mainmenu-98/in-the-press-mainmenu-101/77-in-the-press/1750-a-warning-to-america -speech-geert-wilders-cornerstone-church-nashville-12-may-2011).

58 Wilders, supra note 49.
} 
The passage is noteworthy for several reasons. First, the wealth of detail about a World War II battle given in a speech about Islam is impressive. ${ }^{59}$ Wilders knows how to exaggerate to tell a good story. While the 1944 Ardennes offensive has been called Hitler's last chance, and the $101^{\text {st }}$ Airborne division was surrounded at Bastogne, it was only that unit, and not the entire American army, that was faced with "defeat and death."60

Second, Wilders picked a battle that has played a major role in American popular culture, as films like Battle of the Bulge (1965) and Patton (1970) attest. In choosing to focus on General McAuliffe's rejection of the German surrender offer, Wilders selected an iconic memory from the Second World War. ${ }^{61}$

Third, the way Wilders lionizes General McAuliffe helps to distinguish Wilders from traditional figures of the extreme right who seek to rehabilitate Hitler and the Nazis. ${ }^{62}$ This, in turn, makes it harder to cast him as a typical hate speech defendant. Fourth, Wilders used the brevity of McAuliffe's response- "Nuts!" 33 - to undercut his cultural relativist foes ${ }^{64}$ who seek "explanations" and "caveats" when it comes to responding to the Islamic threat. Like McAuliffe, Wilders is a man of action. Finally, the passage directly links the German forces in the Ardennes to "Мecca" and "the left." In taking this step, Wilders goes beyond his earlier passages, in which he identifies

59 Wilders's self-identification with the victorious American forces also distinguishes him from other far-right supporters of Israel. For example, Filip Dewinter, head of the Vlaams Belang party in Belgium, combines his support of Israel with visits to the graves of Nazi soldiers and the use of the SS oath to open a 2001 speech. See, e.g., Robert Mackey, Support for Israel's Settlements From Europe's Right, N.Y. TIMES (Dec. 22, 2010, 7:01 PM), http://thelede.blogs.nytimes.com/2010/12/22/support-for-israels -settlements-from-europes-right/.

60 For a brief overview, see Donna Miles, Battle of the Bulge Remembered 60 Years Later, U.S. DePT. OF DEFENSE AMERICAN ForCes PRESS SERVICE (Dec. 14, 2004), http://www.defense.gov/news/newsarticle.aspx?id=24591.

61 Miles in her review referred to McAuliffe's response as "now famous." Id.

62 It also distinguishes Wilders from former Senator Joe McCarthy, who first appeared on the national stage in connection with another part of the Battle of the Bulge story. McCarthy argued on behalf of the German SS troops who massacred captured American soldiers in the Belgian town of Malmedy on December 22, 1944. See RoBERT GrIFFITH, THE POLITICS OF FEAR: JosePH R. MCCARTHY AND THE SENATE 20-26 (1970).

63 Apparently, when McAuliffe originally received the surrender order, he told a fellow soldier "Us surrender? Aw, nuts!" After a while, he realized some response was necessary at which point the soldier suggested McAuliffe use his original response. See "NUTS!" Revisited; An Interview with Lt. General Harry W. O. Kinnard, THE DROP ZONE, http://www.thedropzone.org/europe/Bulge/kinnard.html (last visited Aug. 15, 2012).

64 Earlier in the speech, Wilders talked about "the surrender ideology of cultural relativism.” Wilders, supra note 49. 
himself as the victorious Allies, and now compares his foes to the vanquished National Socialists.

A final reference to "the good war" concerns one specific way Wilders justifies his comparison of the Quran with Mein Kampf. He notes that Winston Churchill, who in the 1930s advocated standing up to Hitler, made the same comparison. For example, in his 2009 Columbia University speech, Wilders said that "the great Winston Churchill was fully right when he, in his book The Second World War, called Adolf Hitler's Mein Kampf the new Koran of faith and war. $" 65$

It is worth noting that, as a factual matter, Wilders's invocation of Churchill is subject to question. Churchill was referring to the Quran to call attention to Mein Kampf. ${ }^{66}$ Wilders is using a different understanding of Mein Kampf-one shaped by the Holocaust-to tarnish the Quran. ${ }^{67}$ Furthermore, Churchill-like Wilders-has very little to say about the comparison itself, aside from noting the "turgid, verbose [and] shapeless" nature of the prose in each book. ${ }^{68}$ This suggests a larger problem with the Quran / Mein Kampf comparison (and with the use of the term "Islamofascism" more generally): it is hard to compare "an 800 page monologue exposing Hitler's insane worldview", 99 to the founding text of a major world religion. ${ }^{70}$

\footnotetext{
65 Wilders, supra note 55.

66 See Winston S. Churchill, The SeCOND World WAR: The GATHERING STORM 50 (Mariner Books, 1986). In a page long description of Mein Kampf, the only reference to the Quran is in the "faith and war" sentence. $I d$.

67 Churchill does have other negative comments about Muslims, which Wilders has used in other places. For example, in a speech entitled, "My message to Muslims," explaining how he became anti-Islam, Wilders quoted Churchill's description of the "fearful fatalistic apathy" of Muslims and his (Churchill's) conclusion about the Quran that "No stronger retrograde force exists in the world." Geert Wilders, My Message to Muslims, Muslims DeBATE (Jul. 19, 2010), http://www.muslimsdebate.com/search _result.php?news_id=4399. The Churchill reference appears to be from 2 WINSTON SPENCER CHURCHILL, THE RIVER WAR: AN HISTORICAL ACCOUNT OF THE RECONQUEST OF THE SOUDAN 247 (1899). The book describes the British campaign against the Madhist revolution in the Sudan.

68 CHURCHILL, supra note 66, at 50.

69 The comment comes from Wolfgang Benz, director of the Center for Antisemitism Research at the Technical University of Berlin, who was arguing against releasing a version of Mein Kampf with commentary. Smith, supra note 4.

70 For a criticism of Islamofascism along these lines, see Gabrielle Marranci, $A$ Wolf in Sheep's Clothing: The Neologism 'Islamofascism, ' 8-13, in Thinking Thru' Islamophobia Symposium (May 2008), available at http://independent.academia.edu/YahyaBirt/Papers 1742095/Governing_Muslims_after_9_11. Marranci, an Italian anthropologist, argues that fascism - unlike radical Islam—is characterized by "a nationalist movement, based on the strong leadership of a Dux" and "an autarkic and protectionist view of economy, and is very suspicious of any form of religion.” Id. at 9 . She does, however, find an element of
} 
On the other hand, just as Churchill was an early opponent of Hitler, Wilders can cast himself as an early opponent of Islam. This fits well with Wilders's references to the Normandy beaches, the Battle of the Bulge, his support for Israel, and his call for the Dutch to re-examine their passivity during the Holocaust. Each of these references associates Wilders with the "good guys" in World War II. This positioning, in turn, not only makes it easier to lump Islam and national-socialism together, it makes it harder for Wilders's political opponents to cast him as a right-wing extremist in the mold of JeanMarie Le Pen or Jorg Haider. ${ }^{71}$

\section{V}

\section{Perhaps Wilders Is A Fascist AfTer All}

And yet they do. As we have seen, Henk Bovekerk, a Dutch college student, received a " 10 " for a thesis stating that Wilders is a fascist. He is not alone. Bovekerk's thesis relies heavily on a pamphlet titled, The Eternal Return of Fascism, a pamphlet Dutch philosopher Rob Riemen wrote and distributed to all members of the Dutch parliament in $2010 .^{72}$ Riemen writes:

What you can clearly see with Wilders is the cultivation of feelings of unease and fear in society. Societal unease is blamed on a single scapegoat: Muslims. He is also an authoritarian, charismatic leader who has little time for democracy. As with the fascists in the 1930s,

pre-fascist rhetoric in the tendency of neoconservative proponents of the Islamofascism concept to speak of "Civilization," "Intellectual enemies," and "real Truths." Id. at 10.

71 One interesting aspect of Wilders's speeches about Islam is the absence of references to Soviet Communism, a comparison often made by proponents of the Islam = fascism position. For example, Andrew Bostom, in a 2010 blog post about Wilders, invokes a 1954 article from Bernard Lewis that spoke of the similarities between Islam and Sovietstyle totalitarianism. See Andrew Bostom, Geert Wilders, Bernard Lewis, Free Speech, and Totalitarian Islam, ANDREWBOSTOM.ORG (Oct. 17, 2010), http://www.andrewbostom.org /blog/2010/10/17/geert-wilders-bernard-lewis-free-speechand-totalitarian-islam/. This also distinguishes Wilders from Flemming Rose, who in describing his views about Muslims draws on his experiences as a journalist in the Soviet Union. See Kahn, supra note 12, at 258-60. The difference here may relate to the historical experiences of the Netherlands and Denmark. While Denmark was a frontline state during the Cold War, the Netherlands was somewhat insulated from Cold War tensions. Conversely, the Nazi occupation was much harsher in the Netherlands than in Denmark.

72 Bovekerk, supra note 25, at 5-6. For more on Riemen, see Michel Hoebink, "Wilders is a Fascist," RADIO NETHERLANDS WORLDWIDE (Nov. 8, 2010, 6:19 PM), http://www.rnw.nl/english/article/wilders-a-fascist. Riemen is founder of the Nexus Institute, which has invited speakers such as Jürgen Habermas and Francis Fukuyama. 
the Freedom Party is more a movement than a party and Wilders avoids all debate with his opponents outside of parliament. ${ }^{73}$

In response, historian and former Member of Parliament for the center-right Party for Freedom and Democracy (Volkspartij voor Vrijheid en Democratie-VVD) Arend-Jan Boekestijn called the comparison a "conversation killer" noting that it would "cast doubts on the motives of one and a half million Wilders voters." "H4 He added that "[f]ascism is a serious accusation" which involves "glorification of violence, political dictatorship and-in the German varietyracism." ${ }^{\text {,7 }}$

Boekestijn does a great job of highlighting the stakes of an accusation of fascism. ${ }^{76} \mathrm{~A}$ fascist supports violence, is a potential dictator, and supports "German" racism. Wilders, who sides with the Americans in the Battle of the Bulge, opposes the Quran for its violence and opposes Dutch passivity during the Nazi occupation seems fairly insulated from this charge. And yet the charge persists.

The question is why. To explore this, a look at recent Dutch history is helpful. In 1995 Hans Janmaat was tried, and convicted of hate speech charges. His offense was to say "we shall abolish the multicultural society as soon as we get a chance and get in power.",77 A 2008 op-ed piece in the $N R C$, a Dutch newspaper, looking back on the Janmaat trial from the perspective of Wilders, called Janmaat's comments "almost polite" and said that the prosecution was now seen as unwarranted. ${ }^{78}$ Yet the same author also pointed out that Janmaat was "an extreme right-wing member of parliament with an antiimmigrant message,"79-qualities that before the rise of Pym Fortuyn and Geert Wilders were outside the anti-fascist consensus.

A brief description of Janmaat and his Centre Democrat party may explain why. In addition to imposing curbs on immigration, Janmaat sought to restrict cabinet positions to Dutch nationals, a category for

\footnotetext{
73 Hoebink, supra note 72 (quoting Riemen).

74 Id. (quoting Boekestijn).

$75 \mathrm{Id}$.

76 There are other arguments about Wilders's potential fascism that do not involve World War II. For example, a writer from a socialist perspective argued against the comparison given the PVVs lack of a "street presence"-a key part of earlier fascist movements. See Maina van der Zwan, Geert Wilders and the Rise of the New Radical Right, 131 INT'L SOCIALISM (June 28, 2011), available at http://www.isj.org.uk/?id=743.

77 See Processen als die Tegen Wilders: Zij Werden Wél Veroordeeld, VOLKSKRANT (Neth.) (June 23, 2011) (describing prosecution of Janmaat).

78 Folkert Jensma, Freedom of Expression or Freedom to Insult?, NRC.NL (Mar. 27, 2008), http://vorige.nrc.nl/article1886350.ece.

$79 \mathrm{Id}$.
} 
him that excluded Jews. ${ }^{80}$ This led to a perception that the Centre Democrats were a rightwing extremist party and led to a variety of actions being taken against them, including a concerted effort by mainstream parties to prevent the Centre Democrats from achieving parliamentary representation. ${ }^{81}$ This was not unusual-the electoral successes of right-wing extremists, such as Jean-Marie Le Pen and Jorg Haider met with a similar response. ${ }^{82}$ In a Europe traumatized by the Second World War, Nazi occupation, and the Holocaust, there was great effort placed on avoiding the type of elite toleration of right-wing extremists that scholars like Robert O. Paxton saw as easing Hitler's path to power. ${ }^{83}$ As a result, politicians in Europe (and the Netherlands) were suspicious of parties that appear to follow in Hitler's footsteps.

While Janmaat seemed to fall in this category, applying this label to Wilders poses a much greater challenge. And yet a number of people made just that argument. For example, Jérôme Jamin, who studies politics and philosophy at the University of Liege, described Wilders as part of a "new" right-wing extremism in which racist appeals play a more covert role. ${ }^{84}$ This new images is well suited to a country like the Netherlands, which views itself as "open" and "tolerant." 85 But any change on Wilders's part, says Jamin, is superficial-while the words and faces have changed, the need to identify an "other" as an enemy has not. ${ }^{86}$

The desire to unmask Wilders as a "fascist" can lead to interesting results. For example, Bovekerk describes one of the qualifying aspects of fascism as an emphasis on "the gut rather than the brain,"

80 Guide to the Main Political Parties, NIS News Bulletin, (May 3, 1994), available at http://www.nisnews.nl/dossiers/immigration/030594_54.htm.

81 Hans Janmaat (1934-2002), HISTORIEK.NET (Neth.) (Jan. 17, 2008), http://historiek .net/overige/personen/personen-algemeen/214?tmpl=_print\&print=1\&page=.

82 See Cas Muddle, Conclusion: Defending Democracy and the Extreme Right, in WESTERN DEMOCRACIES AND THE NEW EXTREME Right CHALleNGE 193, 194-95 (Roger Eatwell \& Cas Muddle eds., 2004) (describing efforts of French and Austrian mainstream parties to keep the National Front and Freedom Party out of power).

83 Bovekerk, who relies heavily on ROBERT O. PAXTON, THE ANATOMY OF FASCISM (2004), makes this argument. See Bovekerk, supra note 25, at 25 (citing PAXTON, at 9697). Whether this argument is historically accurate-there are many competing explanations for Hitler's rise to power (Versailles, the Great Depression, etc.) - matters less than its continuing hold on postwar European elites.

84 Jérôme Jamin, Vieilles Pratiques, Nouveaux Visages: Geert Wilders et l'Extrême Droite en Europe, 55 VACARME 43-45 (2011).

$85 \mathrm{Id}$. at 43.

$86 I d$. at 45 . 
an idea he takes from Paxton's The Anatomy of Fascism. ${ }^{87}$ To show that Wilders satisfies this standard, Bovekerk relates how a journalist who infiltrated Wilders's media operation was told not to "go too deep into the material" and not to discuss "nuance" with "outsiders" lest "[e]verybody . . . fall asleep," starting with journalists. ${ }^{88}$ Another article, while not directly calling Wilders a fascist, noted his tendency to use short, direct sentences that lack clauses that attribute meaning away from the author of the sentence. ${ }^{89}$

Bovekerk has other arguments, however, that carry more weighteven if some of them apply better to Wilders's supporters than to Wilders himself. For example, he argues that fascist leaders and parties have a tendency to "discredit" the left, the way fascist parties did during the interwar years. ${ }^{90}$ In making the argument with regard to the PVV, Bovekerk relies on De Schijn-Élite van de Valse Munters [The Fake Elite of the Counterfeiters] a book written by Martin Bosma, a PVV member who argues that the real lesson of the Second World War was not the racism, authority, or hostility of the Nazi state. Rather, it was, to use Bovekerk's summary, that "[e]conomically, Hitler was a socialist and therefore a Left-winger." Bovekerk also quotes J.J. De Ruiter, who describes Bosma's world view in similar words: "The current Left is the heir of Hitler and his band, and of the guilt of many of the deaths of World War II."

While none of these comments are attributable to Wilders, he speaks of the "combined forces of Mecca and the left" as enemies in his Four Seasons speech where he took up the Battle of the Bulge. ${ }^{93}$ Moreover, the Hitler = Socialist formula takes on a revisionist, neoNazi cast to the extent that it shifts responsibility for Hitler's crimes away from the National Socialists. ${ }^{94}$ This may be one reason why, despite his support for Israel, Dutch Jewry, and an apology for Dutch

\footnotetext{
87 Bovekerk, supra note 25, at 48.

$88 I d$. at $48-49$.

89 Maarten Van Leeuwen, “Clear vs. "Woolly" Language Use in Political Speeches: The Case of the Controversial Dutch Politician Geert Wilders (2009), available at http://www.pala.ac.uk/resources/proceedings/2009/vanleeuwen2009.pdf. Van Leeuwen calls Wilders a "controversial" politician who addresses his audiences with "radical standpoints" that break through "political etiquettes." Id. at 1, 2.

90 Bovekerk, supra note 25, at 41.

$91 \mathrm{Id}$. at 47.

$92 \mathrm{Id}$. at 46 (quoting De Ruiter).

93 Wilders, supra note 49.

94 In this regard, Bosma's arguments bear some resemblance to efforts the far right to deny the Holocaust and restrict Hitler's involvement in it in order to undermine any "taboo" on anti-Semitism the Holocaust may have created.
} 
passivity during the Holocaust, Wilders's anti-fascist bona fides are still suspect. ${ }^{95}$

Bovekerk's final argument is that fascists have an "us versus them" view of the world. ${ }^{96}$ According to Bovekerk, Wilders distinguishes between "good, tolerant and democratic Holland" and "bad, intolerant and undemocratic Islam." 97 To that end, Wilders favors preventative detention of Muslims who threaten the state, closing the border to "non-western immigrants (Turks and Moroccans)" for five years, a ban on the construction of mosques, and a replacement of the ban in the Dutch constitution on religious discrimination with a statement that "[C]hristian/[J]ewish/humanistic culture should remain dominant in the Netherlands." policies towards the "alien and the impure"” show how the PVV, "driven by nationalism and racism, divides the world along Manichean lines.”99 This characteristic, along with Wilders's discrediting of the left and his penchant for speaking to the gut, qualifies Wilders, at least for Bovekerk, as a prototypical fascist. ${ }^{100}$

But hidden in Bovekerk's language there is a caveat. By "prototypical,” Bovekerk means “early stage."101 In fact, in defending his thesis that Wilders is a "fascist" he is careful to explain that one should not expect him to act like Mussolini or Hitler; this only comes much later, if at all. ${ }^{102}$ It also turns out that, for Bovekerk at least, "[f]ascism exists at the level of Stage One [i.e. prototypical Fascism] within all democratic countries," a concession that weakens his conclusion. ${ }^{103}$ What is more, there are other, rather critical ways of

\footnotetext{
95 The clash between the competing images of Wilders-participant in the Good War against Nazi Germany or potential fascist-came to a head following a visit by Wilders to Monschau, Germany, a town on the northern shoulder of the Battle of the Bulge. The mayor, citing Wilders's right-wing populism, asked that he not return. Wilders Niet Meer Welkom in Monschau, DE TELEGRAAF (Neth.) (Mar 16, 2010), available at http://www.telegraaf.nl/binnenland/6295972/_Wilders_niet_meer_welkom_in_Monscha u__.html. In response, Diana West wrote a letter to the mayor saying that her father visited the town in 1944 as part of the 102nd Cavalry Reconnaissance Squadron where, like Wilders today, he fought to preserve liberty against "supremacist totalitarianism.” Letter from Diana West to Margareta Ritter, Mayor of Monschau (Mar. 16, 2010) (available at http://www.dianawest.net/Home/tabid/36/EntryId/1319/Dear-Mayor-of-Monschau.aspx).

96 Bovekerk, supra note 25, at 31.

97 Id. at 32.

98 Id. at 32-33, 36-37 (quoting Wilders).

$99 \mathrm{Id}$. at 40.

$100 \mathrm{Id}$. at 59.

$101 \mathrm{Id}$. at 26.

$102 \mathrm{Id}$. at 19.

$103 \mathrm{Id}$. at 27.
} 
viewing Wilders that do not rely on fascism. For instance, John Bowen makes the argument that Wilders's anti-Islamic argumentsespecially those about toleration of gays and women's rights—reflect how not too long ago "most Dutch people held religious views about homosexuality and women's rights that were not too different from those now ascribed to Muslims by their opponents." ${ }^{104}$ According to Bowen, Wilders - and others like him — are using the Muslim migrant as a space in which to work out their own heritage. ${ }^{105}$ One might argue with some force that the Dutch opponents of Wilders do much the same when they debate about whether or not he is a fascist.

\section{VI}

\section{LIKE JEWS IN THE 1930S}

But there is a second, more telling parallel to the Nazi past. Are Muslims the new Jews? As we have seen, this comparison was made by Labor Party leader Job Cohen, who put an emphasis on the "singling out" process. ${ }^{106}$ Interestingly, he made this statement despite being well aware, as former mayor of Amsterdam, of the antiSemitism of some Muslim youth. ${ }^{107}$ Manfred Gerstenfeld, who has written at length about Muslim anti-Semitism, also gives credence to the comparison. He relates how Liesbeth van der Horst, director of the Resistance Museum in Amsterdam has to comfort Moroccan children who visit the museum and conclude: "The Jews were a group that stood apart in Dutch society and were deported. We are today a separate group so that could happen to us." ${ }^{\text {"108 }}$ To hammer home the point, Gerstenfeld asks: if "[s]upposedly well-integrated Jews, those who resemble other Dutchmen so closely that they are often hardly recognizable as Jews, are not seen as authentic Dutch by many Dutchmen ... . what can Muslims expect regarding their integration into Dutch society?’109

104 John R. Bowen, Europeans Against Multiculturalism: Political Attacks Misread History, Target Muslims, and May Win Votes, Bos. ReV. (July-Aug. 2011), http://boston review.net/BR36.4/john_r_bowen_european_multiculturalism_islam.php.

$105 I d$.

106 Cohen, supra note 26.

107 For example, as mayor of Amsterdam Cohen had to determine what slogans could be allowed at a pro-Palestinian rally. Cohen accepted "anti-Israel slogans, but not antiJewish ones." He rejected "a banner equating a swastika to a Star of David" because "[t]he swastika is so connected to racism that it crosses a line.” Gerstenfeld, supra note 35.

108 Gerstenfeld, supra note 38. According to Gerstenfeld, van der Horst reassured the children by pointing out that the Germans, not the Dutch, organized the mass killings of Jews. Id.

109 Id. 
From this perspective, Arend-Jan Boekestijn's explanation that more than a million and a half Dutch voted for Wilders is less reassuring. To the contrary, it reinforces the concern that the antiMuslim measures Wilders endorses have a fair measure of public support. The argument is further reinforced by public opinion surveys registering the fear of Wilders in the Muslim community. For example, Wilders's weblog contains an article from the English language website of NRC Handelsblad, entitled "Half of Dutch Muslims wants [sic] to leave because of Wilders." 110 The article reports that $57 \%$ of Dutch Moroccans and Turks feel less comfortable given the growing popularity of the PVV, 75\% thought Wilders had intensified negative feelings against Muslims, while nine in ten thought a Wilders government would be a "fiasco." 111 Moreover, the same survey that found only $53 \%$ of Dutch citizens would accept a Jew as prime minister, was even worse for Muslims-only 27\% would accept a Muslim prime minister. ${ }^{112}$

When one views the Nazi past not through Wilders's status as a fascist, but from the perspective of Muslims as potential victims, the case for prosecuting Wilders becomes clearer. If the $75 \%$ of the survey were correct in thinking that Wilders "intensified negative feelings" against them, and this could be traced to specific comments Wilders made, then one has the basis of a hate speech prosecution. ${ }^{113}$ The prosecution would rest on the power of Wilders's comments to inspire acts of hate and discriminatory violence. The charges would not depend on whether Wilders satisfied Henk Bovekerk's (or Robert Paxton's) criteria for fascism. Nor could Wilders escape the charges by pointing to his support of Jews, his opposition to Muslim antiSemitism, or his appreciation of the acts of valor for the Western Allied soldiers in World War II.

To a large extent, this is how the prosecution unfolded. Most of the charges against Wilders involved statements about immigration, street crime, and other subjects that-unlike the Mein Kampf / Quran comparison-did not directly invoke the Nazi past. And, as noted above, the court that ultimately acquitted Wilders had the most

110 Half of Dutch Muslims wants to leave because of Wilders, RADIO NETHERLANDS WORLDWIDE (June 30, 2009), available at http://www.geertwilders.nl/index.php?option =com_content\&task=view\&id=1590.

111 Id.

112 Gerstenfeld, supra note 38.

113 The threat is even greater given that Wilders posted an article about the polling data on his weblog, in effect sending the message that he is glad Muslims are scared. 
trouble with his call to Dutch citizens to confront Muslims in the streets. ${ }^{114}$ (On the other hand, the Amsterdam Appeals court-which authorized the charges in 2009-placed great emphasis on Wilders's use of the Mein Kampf and fascist labels. It mentioned "Mein Kampf," "fascist," or "Nazi” over 30 times in its opinion—although most of these references were not substantive). ${ }^{115}$

And yet the prosecution of Wilders still took place in the shadows of the Holocaust. One of the legacies of the Holocaust is a heightened sensitivity to the power of words to cause harm. Small things that would not otherwise attract attention do so if they involve the Nazi past. For example, last winter a number of branches of the British bookstore Waterstones placed stickers on Mein Kampf, describing it

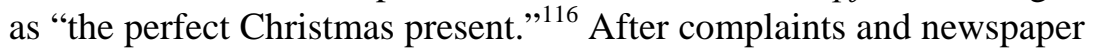
coverage, the bookstore apologized. Likewise, the Amsterdam trial court's conclusion that Wilders's call to confront Muslims in the streets was at the border of the acceptable might reflect a sensitivity to the special status of Dutch Muslims in a society that has yet to fully work out its own issues with the Holocaust.

\section{Conclusion: The Continuing Relevance Of THE NAZI Past}

The debate over "fascism" at the Wilders's trial raises an additional, more general question, one about the discourse over European hate speech laws in the United States, home of the First Amendment. At first, this would seem to be a match made in heaven. Wilders himself has called for a First Amendment for Europe. ${ }^{117}$ In addition, proponents of free speech libertarianism, such as Robert Post, tend to downplay the role of Europe's Nazi past in explaining the persistence of hate speech laws there. For example, in a recent book chapter, Post traces Europe's hate speech laws to a number of factors, including "European habits of deference to political

\footnotetext{
114 Wilders Verdict, supra note 12, § 4.3.2.

115 In reading the opinion one gets the sense that the judges were shocked by the comparison - which may be why, when the court turned to its analysis of the case it introduced "Nazi" into the analysis, a word Wilders never used. See Gerechtshof Amsterdam (Amsterdam Court of Appeals) 21 Jan. 2009, NJ 2009, 191 m. nt. Y. Buruma, $\S \S 12.1 .3,12.2 .2$, and 13 .

116 U.K Bookseller Apologizes for Promoting 'Mein Kampf' as Perfect Christmas Present, Fox NEws (Dec. 23, 2011), http://www.foxnews.com/world/2011/12/23/uk -bookseller-apologizes-for-promoting-mein-kampf-as-perfect-christmas-present/. The stickers also described the book as "essential read[ing]" for anyone. Id.

117 See Adriana Stuijt, Dutch MP Geert Wilders on Fox TV: Europe Needs a First Amendment, Digital JouRnAL (Feb. 24, 2009), http://digitaljournal.com/print/article /267899.
} 
authority," but does not make direct reference to the Holocaust or the Nazi occupation. ${ }^{118}$ He adds that Holocaust denial bans are not only "problematic" but also "rare." "119 Treating such laws as rare is part of a larger strategy of placing European hate speech laws in a broader context, one that makes them seem unreasonable. ${ }^{120}$

Peter Teachout, writing about Holocaust denial, takes a slightly different tack. He concedes that "[d]uring the period immediately following the War . . . there was real and important urgency in establishing once and for all that civilization would never again tolerate what had been done in the name of Aryan superiority."121 Now, however, more than sixty years after World War II, there have been "profound changes,"122 ones that make anti-denial laws less urgent. These include greater documentation of the Holocaust, the use of the European Union to bind Germany into a web of connections that make the re-emergence of the Nazi past inconceivable, and greater Holocaust education. ${ }^{123}$ This leads Teachout to wonder if antidenial laws "have not become anachronistic."124

Whatever one thinks of Post and Teachout's views of hate speech laws from a normative perspective, ${ }^{125}$ they underestimate the extent to which the Nazi era, including the Holocaust, plays in European understanding of hate speech laws. Laws against Holocaust denial are not rare in Europe- to the contrary a number of European countries have such laws, and for a while Europe-wide bans were seriously

118 See Post, supra note 13, at 137.

119 Id. at 127.

120 For instance, Post's analysis of hate speech laws refers to the first English translation of Machiavelli's The Prince (which contained an admonition to avoid stirring up hatred) and the 1792 conviction of Tom Paine for seditious libel. Id. at 125-26.

121 Teachout, supra note 13, at 688.

122 Id. at 692.

$123 I d$. at 688-89 n.149.

124 Id. at 692.

125 Some scholars in the United States take a more favorable view of permissibility of hate speech laws in the United States. For instance, Alex Tsesis suggests the First Amendment might not protect "forms of hate speech" that, even if not intimidating, could “incite an audience to commit discrimination at work or in public places." See Alexander Tsesis, Dignity \& Speech: The Regulation of Hate Speech in a Democracy, 44 WAKE FOREST L. REV. 497, 532 (2009); see also ERIK BLEICH, FREEDOM TO BE RACIST? HOW THE United States AND Europe StRuggle to PRESERVE FreEdOM AND Combat RACISM 79-80 (2011) (noting how differences between United States and European regulation of speech diminish when one looks at "hostile environment" claims brought in the employment law context). 
considered. ${ }^{126}$ And while Teachout is free to call the need for antidenial laws "anachronistic," the laws themselves came into existence relatively recently. For example, the French Gayssot Act was passed in 1990, a time when-according to Teachout-concerns about the Holocaust should have been in decline. ${ }^{127}$

The repeated references to the "fascists," Mein Kampf, and the situation of the Jews in the 1930s at the Wilders trial suggest that fears about the Holocaust and the Nazi past, far from being "anachronistic," are alive and well in postwar Europe nearly seventy years after V-E day. ${ }^{128}$ This does not mean one has to approve of this state of affairs ${ }^{129}$ - one might, from a libertarian perspective, bemoan the impact that the events of the 1930s and 1940s have had on European hate speech law. In his book about Holocaust-related trials, Lawrence Douglas has questioned whether law is capable of speaking "adequately on behalf of humanity's most traumatic histories." "130 One can ask the same question about speech regulation. Is a postHolocaust Europe ready for a First Amendment? Or is the anti-fascist consensus behind hate speech laws a sign of how the Holocaust has left a continuing rupture in the fabric of European society? ${ }^{131}$

126 Currently a number of European countries including Belgium, France, the Netherlands, Germany and Austria ban Holocaust denial. See Kahn, supra note 3, at 96 n.104 (2011) (noting situation as of 2011). For an overview of efforts to establish a European ban on Holocaust denial, see Laurent Pech, The Law of Holocaust Denial in Europe: Toward a (Qualified) EU-Wide Criminal Prohibition, in GENOCIDE DENIALS AND THE LAW 185 (Thomas Hochmann \& Ludovic Hennebel eds., 2011).

127 For a brief overview of the passage of the Gayssot Act, see Kahn, supra note 33, at 105-08.

128 Similarly, one could read Virginia v. Black, 538 U.S. 343 (2003), which allowed states to ban some forms of cross burning as showing that slavery and segregation are not yet "anachronistic" concerns in the United States. See Robert A. Kahn, Did the Burning Cross Speak? Virginia v. Black and the Debate between Justices O'Connor and Thomas over the History of Cross Burning, 39 STUD. L. POL. \& SOC'Y 75 (Austin Sarat ed., 2006) (describing debate between Justices O'Connor and Thomas over the history of cross burning in the United States).

129 Likewise, one can question whether the fear of a Nazi or fascist resurgence in current day Europe is a realistic possibility. On this issue, Teachout is right to point out that times have changed since 1945. Teachout, supra note 13, at 688-92. On the other hand, even if fears of a Nazi resurgence are irrational, they are an important part of European discussions about hate speech laws.

130 Lawrence Douglas, The Memory of Judgment: Making LaW \& History in THE TRIALS OF THE HOLOCAUST 261 (2001).

131 Perhaps the strongest evidence for a continuing rupture-one related to hate speech laws - comes from Germany where anti-Semitic incidents and judicial opinions favoring Holocaust denial led to calls for tougher enforcement hate speech laws. KAHN, supra note 33, at 67, 73-77. While these events date back to the 1960s, perhaps the largest scandal arose in 1994 when Judge Ranier Orlet was placed on emergency medical leave after praising defendant Günter Deckert—whom he had just found guilty of racial incitement by 
Regardless of how one answers these questions, the questions themselves attest to the continuing influence of the Nazi past on debates in Europe over banning hate speech. Perhaps Europeans should try to move beyond the past, or - to use Teachout's wordsperhaps "[i]t is time [for Europe] to trust again in democracy."132 One might even agree with Teachout and Post that laws against Holocaust denial should be "rare." Indeed, the rancor and confusion caused by the competing charges of fascism at the Wilders trial may well cause someone to long for a time when the Nazi era ceases to loom as large over European public life.

But the time has not yet come. In 2012, Europeans are still dealing with the Holocaust. This year has already seen Manfred Gerstenfeld's call for a Dutch apology for passivity during the Holocaust. ${ }^{133}$ In addition, a Dutch filmmaker is currently standing trial for filming a former Dutch Nazi in a German nursing home. ${ }^{134}$ Meanwhile, a German prosecutor is seeking prison for an 89-year-old man accused of war crimes in the Netherlands. ${ }^{135}$ Perhaps it will take another generation - one in which the last victims, perpetrators, or bystanders have passed away-to move to a genuinely post-Holocaust perspective on hate speech law.

This may happen one day. But doubts remain, in part because of how the Nazi past (and especially the Holocaust) has become part of a broader discourse about the rejection of "racial and religious bigotry."136 Here, Khaled Abou El Fadl's essay on Geert Wilderswritten while El Fadl was in the Netherlands as a visiting professoris enlightening. El Fadl begins by discussing the rise of Geert Wilders. ${ }^{137}$ He notes that Islam bashing has become a "lucrative

denying the Holocaust-for raising questions about "Jewish pretensions about the Holocaust." Id. at 154. In the ensuing debate, concerns were raised about "Germany's reputation abroad," $i d$. at 73 (quoting then Chancellor Helmut Kohl), as well as the impact of denial on the political legitimacy of the Federal Republic of Germany. Id.

132 Teachout, supra note 13, at 692.

133 See supra note 32 and accompanying text.

134 Dutch Journalists to Stand Trial for Filming Nazi, RADIO NETHERLANDS WORLDWIDE (Jan. 19, 2012, 10:57 AM), available at http://www.rnw.nl/english/print /592790.

135 David Rising, German Prosecutor Seeks to Jail Nazi War Criminal, SEATTLE TIMES (Jan. 19, 2012), http://seattletimes.com/html/nationworld/2017274945_apeuger many nazicriminal.html. Since then, the person in question-Klass Carel Faber-has died. See Nazi War Criminal Klaas Carel Faber Dies in Germany, BBC NEWs (May 26, 2012), http://www.bbc.co.uk/news/world-europe-18219795.

136 See Khaled Abou El Fadl, Editorial, Fascism Triumphant?, 10 POL. THEOLOGY 577, 577 (2009).

137 Id. 
industry"138 and asks whether Wilders realized that he and his supporters were "marching down the same path of every other fanatic who used fear and hate to demonize millions of people." ${ }^{139}$ El Fadl refers to the Bosnian Genocide, the Serbian rape camps, and the Armenian Genocide, ${ }^{140}$ before concluding his article by describing how in the 1930s an "extreme and puritanical nationalism" led to the Holocaust. ${ }^{141}$

Like Cohen and Gerstenfeld, ${ }^{142}$ El Fadl traces a connection between a history of European anti-Semitism culminating in the Holocaust and current anti-Muslim sentiment. In doing this, all three authors help bridge a divide between those who argue that antiSemitism and the Holocaust belong solely to history and those who argue that European Muslims-in part because of their lack of understanding of the Holocaust - are contributing to a new wave of anti-Semitism. ${ }^{143}$ The example of Jewish and Muslim writers accepting this comparison suggests that even if one argues that Islamophobia has replaced anti-Semitism as the primary expression of European xenophobia, the experience of the Nazi past will still inform Europeans' understanding of racism and hate speech regulation. ${ }^{144}$

In the meantime, sweeping the past under the rug in the name of a universal theory of speech protection (one based largely on the historically contingent experiences of the United States) ${ }^{145}$ will not advance our understanding of the Wilders trial or of the current

\footnotetext{
$138 \mathrm{Id}$. at 578 .

139 Id.

$140 \mathrm{Id}$.

$141 \mathrm{Id}$. at 581

142 See supra notes 106-09 and accompanying text.

143 Robert Fine, Fighting with Phantoms: A Contribution to the Debate on Antisemitism in Europe, 43 PATTERNS OF PREJUDICE 459, 466-67 (2009). Fine frames the debate over European anti-Semitism as a debate between "alarmists" and "deniers" and calls for creating a "cosmopolitan space" between the opposing camps. Id. at 466-67, 479. Arguably, Cohen, Gerstenfeld, and El Fadl are creating the "cosmopolitan space” Fine is calling for.

144 Likewise, Uladzislau Belavusau, an assistant professor at the VU University in Amsterdam, sees regulation of hate speech as based on not only "a traditional post-war ethos of militant non racism" but also "a newer telos of the peaceful integration of migrants.” Uladzislau Belavusau, Fighting Hate Speech Through EU Law, 4 AMSTERDAM L. F. 20, 34 (2012). Interestingly, Belavusau describes the Wilders acquittal as "controversial" and against the grain of recent punitive measures taken against right-wing politicians. Id.

145 According to Samuel Walker, the departure of the United States from traditional norms - ones that allow for some punishment of hate speech-occurred as a result of the movements in the 1960s for Civil Rights and against the Vietnam War. SAMUEL WALKER, HATE SPEECH: THE HISTORY OF AN AMERICAN CONTROVERSY 104-13 (1994).
} 
efforts by Flemming Rose ${ }^{146}$ and Geert Wilders to challenge hate speech laws and expand protections for freedom of speech in Europe. Nor will it fully explain the sensitive position of Muslims in Europe who are simultaneously seen as potential Nazi censors eager to rob Europeans of their liberties and, at the same time, as the new Jews, victims of the Nazis for whom hate speech laws are meant to protect. $^{147}$

To return to Abraham Foxman, Europeans have "experienced Nazism and other destructive social movements on their soil." ${ }^{148}$ The depth of discussion about fascism at the Geert Wilders trial is a reminder that these movements have had a continuing impact. The same applies to Dutch (and European) hate speech laws. One can object to the methods and (speaking from the United States) point out that they are "not ours." 149 But the "legacy of extremism""150 these laws are meant to protect against is still—at least for many Europeans-quite real. ${ }^{151}$

146 For more on Rose, see Kahn, supra note 12.

147 See, e.g., David A. Jacobs, Note, The Ban of Neo-Nazi Music: Germany Takes on the Neo-Nazis, 34 HARV. INT'L L.J. 563, 572-73 (1993) (describing how anti-Semitic songs from the 1930s were reprised with Turks as the new victims).

148 Foxman, supra note 1, at xiv.

$149 \mathrm{Id}$.

$150 \mathrm{Id}$.

151 For example, Groningen law professor Fokko Oldenhuis, calling Wilders a "hatemonger," pointed out that the first Dutch hate speech law, passed in 1934, was directed to protect Jews against Hitler's rise to power in Germany. Interview with Fokko Oldenhuis, University of Groningen Professor of Religion \& Law, PVV Politician Wilders a Prime Example of Reprehensible Intolerance (Dec. 15, 2009), available at http://www.rug.nl/corporate/nieuws/opinie/2009/opinie09_51. 
